\title{
REVISITING INGARDEN'S THEORETICAL BIOLOGICAL ACCOUNT OF THE LITERARY WORK OF ART: IS THE COMPUTER GAME AN “ORGANISM”?
}

\author{
MATTHEW E. GLADDEN \\ MA in Marketing and Innovation, MBA, Guest Lecturer. \\ Institute of Computer Science, Polish Academy of Sciences. \\ PL-01-248 Warsaw, Poland. \\ E-mail: matthew.e.gladden@gmail.com
}

From his earliest published writings to his last, Roman Ingarden displayed an interest in theoretical biology and its efforts to clarify what distinguishes living organisms from other types of entities. However, many of his explorations of such issues are easily overlooked, because they don't appear in works that are primarily ontological, metaphysical, or anthropological in nature but are "hidden" within his works on literary aesthetics, where Ingarden sought to define the nature of living organisms in order to compare literary works to such entities. This article undertakes a historical textual analysis that traces the evolution of Ingarden's thought regarding the nature of the literary work of art as an organism-like entity and uncovers its links with the simultaneous development of his systems theory and its central concept of the "relatively isolated system": for Ingarden, a literary work and an organism are each a systematically transforming, "living," functional-structural whole that comprises a system of hierarchically arranged and partially isolated (yet interdependent) elements whose harmonious interaction allows the literary work or organism to fulfill its chief function. Having completed that historical analysis, we test Ingarden's assessment of works of art as organism-like entities in a novel context by investigating the organism-like qualities of the contemporary computer game; insofar as their AI-driven behavior displays a form of agency, such games might appear to be even more "alive" than traditional works of art. We show that Ingarden's conceptual framework provides a useful tool for understanding the "organicity" of such games as works of art, despite the fact that they differ qualitatively from those art forms with which Ingarden was directly familiar.

Key words: Roman Ingarden, theoretical biology, organisms, systems theory, relatively isolated systems, philosophical aesthetics, literary works, computer games, Zygmunt Łempicki, Max Scheler.

(C) MATTHEW E. GLADDEN, 2020 


\title{
ВОЗВРАЩАЯСЬ К ИНГАРДЕНОВСКОЙ \\ ИНТЕРПРЕТАЦИИ ЛИТЕРАТУРНОГО ПРОИЗВЕДЕНИЯ: ЯВЛЯЕТСЯ ЛИ КОМПЬЮТЕРНАЯ ИГРА «ОРГАНИЗМОМ»?
}

\author{
МЭТЬЮ Е. ГЛЭДДЕН \\ Магистр инновационного маркетинга, приглашенный лектор. \\ Институт компьютерных наук, Польская Академия Наук. \\ PL-01-248, Варшава, Польша. \\ E-mail: matthew.e.gladden@gmail.com
}

Начиная с самых ранних своих работ вплоть до последних, Роман Ингарден проявлял интерес к теоретической биологии с ее попыткой прояснения различия между живыми организмами и другими видами сущего. Однако многие его исследования в этом направлении упускаются из виду, поскольку они не появляются в работах онтологического, метафизического или антропологического толка, а, скорее, «спрятаны» в его трудах по литературной эстетике, в которых Ингарден стремился определить природу живых организмов с целью сопоставления с ними художественных произведений. В данной статье предпринимается историко-текстуальный анализ, прослеживающий эволюцию мысли Ингардена относительно природы художественного произведения, уподобляемого организму, раскрывая ее связь с развитием его теории систем и центральным в этой теории понятием «относительно изолированной системы»: с точки зрения Ингардена, как художественное произведение, так и организм представляют собой систематически трансформирующееся «живое» функционально-структурное целое. Оно охватывает собой систему иерархически организованных и частично изолированных (хотя и взаимозависимых) элементов, гармоническое взаимодействие между которыми позволяет художественному произведению и организму выполнять свою основную функцию. Завершив этот исторический анализ, мы проверим ингарденовскую концепцию произведения искусства в русле идеи организма в новом контексте, исследуя организмические свойства современной компьютерной игры; в той мере, в какой их поведение, направляемое искусственным интеллектом, являет собой форму агентности, такие игры могут показаться более «живыми», чем традиционные произведения искусства. Мы покажем, что концептуальная система Ингардена предоставляет полезный инструмент для понимания «органичности» этих игр как произведений искусства, несмотря на их качественное отличие от тех форм искусства, с которыми Ингарден был непосредственно знаком.

Ключевые слова: Роман Ингарден, теоретическая биология, организмы, теория систем, относительно изолированные системы, философская эстетика, художественные произведения, компьютерные игры, Яигмунт Лемпицки, Макс Шелер.

\section{INTRODUCTION}

Philosophical aestheticians who are familiar with Roman Ingarden's aesthetic writings will have noticed the occasional places in those texts-most prominently in Das literarische Kunstwerk (1931) and O poznawaniu dzieła literackiego (1937a)_ in which he compares the literary work of art to a living organism. When reading 
such passages, one might easily picture Ingarden as an aesthetician who was using some incidental knowledge of biology to formulate analogies that could be helpful in elucidating the structure and dynamics of literary works. In fact, though, Ingarden's interest in biology was far from superficial, and such analogies were not just casually assembled metaphors; rather, Ingarden was a pioneering thinker in systems theory and theoretical biology who drew on his knowledge of the structure and dynamics of literary works in order to deepen his understanding of biological organisms as particular kinds of "relatively isolated systems"1. Indeed, Ingarden's work on systems theory-developed most explicitly in Über die Verantwortung: Ihre ontischen Fundamente (Ingarden, 1970c; 1983) and Über die kausale Struktur der realen Welt: Der Streit um die Existenz der Welt III (1974)_proved so significant that Sienkiewicz and Wojtala (1991) recognize him as one of the most influential figures in the history of systems theory in Poland. Nevertheless, systems theorists who are interested in Ingarden's theoretical biology may find it difficult to contextualize those references to biological organisms that appear in Ingarden's studies of literary aesthetics.

In this text, we seek to demonstrate the way in which the fields of philosophical aesthetics and theoretical biology were deeply intertwined for Ingarden, by carefully tracing the evolution of his understanding of the (literary) work of art as an organism-like entity. Building on that historical analysis, we then seek to link Ingarden's thought with ongoing developments in aesthetics. In particular, the rise of new digital media and art forms in the half-century since Ingarden's death raises the question of whether the unique characteristics of (for example) narratively and visually sophisticated contemporary computer games might undermine or reinforce Ingarden's analysis of the organism-like nature of works of art. Examining such emerging technologies through the lens of his thought is arguably consistent with the spirit of Ingarden's own philosophical project, insofar as he consciously developed his aesthetics with an eye toward novel types of artistic technologies that might appear in the future ${ }^{2}$. It is hoped that this text's Ingardenian analysis of the organism-like nature of computer games can offer a novel illustration of the continued fruitfulness of Ingarden's thought.

Półtawski $(1978,129)$ argues that from the beginning of his career to its end, Ingarden was at heart primarily a philosophical anthropologist, and his works on aesthetics, ontology, and other subjects were ultimately all aimed at making it possible to better understand the nature of the human being. Indeed, Ingarden's work on theoretical biology and systems theory often focuses on investigating the human being as a unique type of organism and "system."

2 See, e.g., Maluga's $(2006,51)$ observations regarding the way in which Ingarden anticipated and analyzed the aesthetic implications of VR technologies that are only today becoming practical. 


\section{THE ORGANISM AND ISOLATION: \\ EARLY EXPLORATIONS (1919-1928)}

Having been formed through his study with Twardowski and Husserl, Ingarden's first and most natural philosophical vocabularies were those of the Lvov-Warsaw School and "classical" phenomenology, which lack direct theoretical links with the vocabulary of biology. As a result, Ingarden's earliest works approach the analysis of parts and wholes largely from a mathematically and logically oriented mereological-rather than biological-viewpoint (see, e.g., Ingarden, 1925). However, from his earliest writings, Ingarden had also demonstrated an interest in perspectives that he would later come to recognize as belonging to the field of "theoretical biology" — and the eagerness with which Ingarden $(1947,255 ; 1948 b, 161 ; 2013,272)$ explicitly embraced the language and conceptual frameworks of theoretical biology upon first encountering them in Bertalanffy's writings in 1943 strengthens the impression that Ingarden had long understood questions of parts, wholes, and systems in a manner that was broader than what could easily be captured through conventional mereological language.

While typical empirical biology seeks to study the structures and behaviors of those living organisms that actually exist in our world, theoretical biology seeks to analyze the concepts of "life" and the "organism" at a more abstract level; for example, it asks what minimum characteristics an entity must possess in order to be considered "alive." Ingarden's investigation of such questions dates back at least to "W sprawie istoty doświadczenia wewnętrznego", in which he discusses the nature of conscious and non-conscious biological organisms (Ingarden, 1922b, 527-529). More pertinently, in "Essentiale Fragen: Ein Beitrag zum Wessensproblem", Ingarden (1925, 196-197) argues that an "organism" can be identified with an entity possessing many individual parts that play specific and characteristic roles and which demonstrate real relationships of interdependence; a typical "class" or "set" of objects does not-by virtue of being a class or set-constitute such an organism.

Perhaps the conceptual framework that would prove most critical to Ingarden's understanding of the organism is that of "isolation": an entity is (at least partially) "isolated" from its environment when it possesses some boundary that differentiates the "interior" of the entity from its "exterior" and which through its structure or behavior renders the entity more "open" or "closed" to interaction with conscious subjects or other elements of its environment. This language of isolation-of "openness" and "closure" - was present in Ingarden's earliest thought. For example, in "Dążenia fenomenologów", he objects to the view that the soul's mental phenomena are nothing more than a system of dead contents that are closed within themselves (system takich 
zamkniętych $w$ sobie, martwych "treści”), while also discussing the way in which the real world constitutes a whole enclosed within itself (całość $w$ sobie zamknięta) and the manner in which, in Husserl's understanding, pure consciousness constitutes a separate being enclosed within itself (Ingarden, 1919, 121-122, 338, 346).

More significantly, in Intuition und Intellekt bei Henri Bergson, Ingarden (1922a, $353,355)$ notes that for practical purposes, it is possible to think of the world as being divided into many isolated systems; however, in reality, there are "no absolutely closed systems" (keine absolut abgeschlossenen Systeme) but only many "relatively closed systems" (relativ abgeschlossene Systeme). This concept of the relatively closed or partially isolated system would come to undergird many aspects of Ingarden's thought; he would, for example, draw naturally on such language when offering his posthumous reflections on the thought of Scheler, for whom-according to Ingarden (1928, 347) - a human being was not an entity that could exist isolated from the rest of the world but rather a specifically organized living individual (pewnem szczególnie uorganizowanem, żywem indywiduum) that stands in constant contact with the human community and possesses its own characteristic ways of reacting to the dead and living world that surrounds it (otaczajacy je świat martwy $i \dot{z} y w y$ ).

\section{THE LITERARY WORK AS A “LIVING” AND SYSTEMATICALLY TRANSFORMING WHOLE: „DAS LITERARISCHE KUNSTWERK“ (1931)}

Ingarden would soon extend his thinking on theoretical biology and partially isolated systems into the field of aesthetics, devoting Chapter 13 of Das literarische Kunstwerk (1931) to "The 'Life' of a Literary Work." He states explicitly that the word "life" is used in a figurative sense: while clear analogies exist between the "life" of a literary work and that of a living being, there are also many differences (Ingarden, 1931, $356,364)$, as discussed below.

\subsection{The meaning of "life"}

Ingarden's analysis of the "life" of a literary work is complicated by the fact that even in its literal sense, the word "life" had not yet been satisfactorily defined (Ingarden, 1931, 356). Ingarden thus felt obliged to clearly explain the sense in which he would be using the word. For him, "life" has two primary meanings: it is (1) the whole that comprises all the events that a living being experiences from its conception to its death and (2) the "process" by which those events unfold (Ingarden, 1931, 356). 
Regarding the second sense, it is not enough for an object to endure through time (since even "dead" physical objects endure) or to undergo continual change (since a rock that is being worn down by erosion undergoes such change without thereby being "alive"); rather, a living being is characterized by the fact it undergoes continual change occurring within "a particular system of transformations" (ein bestimmtes System von Verwandlungen) that causes the course of the being's life to create a certain kind of unified whole that is typical for living beings (Ingarden, 1931, 356-357).

What exactly is the system of transformations typical for living beings? It is a system that manifests itself through the creation of qualitatively and quantitatively distinct phases, which begin with conception (and a sort of maximal, almost raw, potentiality) and continue through stages of growth and development whose activity guides a being toward a culminating phase of robust maturity, following which the entity begins to break down (with particular changes coming faster or slower), until eventually it dies (Ingarden, 1931, 356).

\subsection{The "opening" and "closing" of the living organism}

Every such living being possesses (or at least appears to possess) an ability to actively respond to those forces that are impacting it; this capacity for directed reaction seems to come from within the living being itself, and it distinguishes it from all "dead" objects, which can only passively undergo various transformations (Ingarden, $1931,357)^{3}$. Such reactive capacity is related to concepts of openness and closure: organisms that possess a soul are able to "open themselves up" („aufschließen“) or "close themselves within themselves" („sich in sich selbst verschließen") before another psychic individual that is attempting to know them ${ }^{4}$; indeed, such organisms may also perform a "closing off of themselves to themselves" (ein „sich vor sich selbst Verschließen") that can be healthy or pathological behavior (Ingarden, 1931, 139). On the other hand, "lifeless" or "dead" objects are indifferent ${ }^{5}$ to their degree of closure and do not open themselves up or close themselves off to other things: while the possibility

3 In the later Polish edition of the work, Ingarden would add a footnote connecting this observation with Scheler's thought as presented in Die Stellung des Menschen im Kosmos (1928); see (Ingarden, 1988, 425).

4 Ingarden $(1931,139)$ associates a soul's ability to seal itself off from others with the "intimate spheres” („Intimsphären“) that Scheler describes in Wesen und Formen der Sympathie (1923).

5 Ingarden $(1974,104,109)$ would further develop this concept of "indifference" in his mature systems theory. 
for an object to manifest "openness” („Aufgeschlossenheit") or "being sealed within itself" ("In-sich-verschlossen-sein") is rooted in the object's structure, the fact that an object actually appears open or closed in a given moment depends on the cognitive subject who is experiencing the object in that way. A given object appears open to us because "we 'unlock' it, so to speak" (wir den Gegenstand sozusagen "aufschließen") (Ingarden, 1931, 139).

\subsection{Two ways in which a literary work of art "lives"}

There are two (figurative) senses in which one can speak of a literary work as possessing such a "life." First, as a schematic construct, the literary work (and any other kind of artwork) "lives" simply by expressing itself through a multiplicity of concretizations (Ingarden, 1931, 359, 362). Second, the work "lives" by undergoing transformations within itself (Ingarden, 1931, 359-60). In this second sense, the work itself lives (and not just its individual concretizations) (Ingarden, 1931, 366). However, once created, a work of art cannot change itself (Ingarden, 1931, 359), as it lacks that sort of agency; such transformation must be driven by those cognitive subjects who engage with the work. A relatively obvious kind of transformation occurs, for example, when an author removes sections from (or adds sections to) a work while preparing a revised edition (Ingarden, 1931, 367) ${ }^{6}$. Indeed, changes that eliminate "unnecessary" parts can actually improve a work by making its internal dynamic more intense, without thereby transforming it into a different work (Ingarden, 1931, 358-359).

Another kind of transformation occurs as a natural result of the fact that the concretizations of a given work fashioned by conscious subjects are always novel and different (Ingarden, 1931, 359-360) — and the differences between concretizations are not random; they undergo an often qualitatively positive or negative "development" over time, which resembles the life cycle of a psychic individual: over the years (or centuries), a given work of art may come to be understood in a different way; it may become beloved and acclaimed for a time, only to later become unpopular or altogether forgotten (and, even later, to potentially undergo a revival) (Ingarden, 1931, 364). This typical cycle of growth, development, maturity, and decline represents an important analogy between the life of a living being and the "life" of a work of art (Ingarden, 1931, 364-365).

6 See also the somewhat different description in Ingarden $(1988,434)$. 


\section{4. ŁEMPICKI'S ANALYSIS OF INGARDEN'S "ANATOMICAL" VIEW OF THE LITERARY WORK (1932)}

An exchange that appears to have thus far been overlooked by researchers studying Ingarden's systems theory but which (we would argue) was pivotal to the development of his theoretical biology occurred when the literary theorist Zygmunt Łempicki published an analysis of Das literarische Kunstwerk in Wiadomości Literackie in 1932 and Ingarden published a reply, "Formy obcowania z dziełem literackiem", in the same periodical the following year.

In particular, Łempicki reflects on Ingarden's account of the literary work's structure as a whole possessing distinct layers. One of Łempicki's key points is to illustrate the way in which Ingarden's analysis had focused primarily on the static, structural elements of the literary work of art, while largely ignoring its more dynamic and active elements. Łempicki $(1932,3)$ suggests that Ingarden has thus offered a "phenomenological" account of the literary-work-as-organism that focuses on its visible "anatomical structure" (anatomiczna budowa) and its "external shell"; however, such an account should ideally be paired with a complementary analysis that focuses on the (literary) organism's invisible internal activity and the functioning of its "organs"and which would thus be more "physiological" than "anatomical" in nature. It is only such a physiological analysis that can hope to identify and understand a literary work's "internal force," its "discharging [...] energy" that externalizes and crystallizes itself in stylistically appropriate forms (Łempicki, 1932, 3). For Łempicki (1932, 3), the literary work is a sort of energy reservoir or charged battery, with the nature of that energy shaped by the particular psychic structure of its creator ${ }^{7}$. In such a physiological account, the literary work of art is an intensely active, energetic entity that is almost endowed with a sort of agency. Its internal energy not only seeks to express itself through the thoughts, speech, and observations of the work's creator or readers (i.e., to ensure that the energy is expressed) but also to shape the particular choice of words, syntax, and larger arrangements of content through which it is expressed (Łempicki, $1932,3)$. Thus, the specific arrangements of printed characters and lines of text on a page are, in a sense, just a byproduct of the literary work's internal force; they are the externally visible ossifications of that unique energy. In order for an arrangement of characters and paragraphs to qualify as a true literary work, it is not enough for it to

Łempicki also introduces the thought of Wilhelm Dilthey into the discussion: in Łempicki's (1932,

3) view, Dilthey had also opposed purely visual analyses of the external structures of a literary work, instead holding the literary work to demonstrate an energy and dynamism whose expression reflects the activity of particular functional systems within the soul of the living human being. 
demonstrate a particular structure; the structure must have been generated by such internal psychically conditioned energy that remains present and active within the work. Otherwise, the structure is simply a lifeless shell-perhaps comparable to the fossilized remains of an animal that has long since died or an imitation animal fabricated from wood and cloth ${ }^{8}$.

Even if his language had been more metaphorical than literal, Łempicki's attempt at a serious analysis of the literary work of art's "anatomy," "physiology," "physiognomy," "organs," "shell," "energy," "force," "action," and associated structure of "systems of psychic functions" seems to have emboldened Ingarden in his own thinking about the organism-like characteristics of certain non-biological entities.

\section{THE LITERARY WORK AS STRUCTURAL-ANATOMICAL AND FUNCTIONAL-ENERGETIC OBJECT: "FORMY OBCOWANIA Z DZIEŁEM LITERACKIEM" (1933)}

Łempicki offered his analysis not as a criticism but as a suggestion for enriching Ingarden's model of the literary work of art, and Ingarden responded in kind, graciously accepting Łempicki's suggestions. Comparing his own "anatomical" account of the literary work with Łempicki’s "energetic" analysis, Ingarden $(1933,3)$ contends that not only are the two treatments not mutually exclusive, but his phenomenological analysis of the structure of the literary work as a multilayered whole provides a useful foundation upon which to carry out precisely such "energetic" analyses 9 . In other words, Ingarden here recognizes the literary work's (1) enduring structure and (2) dynamic activity as two distinct yet interrelated constituent elements of the work, as two complementary perspectives through which it might be viewed. In this way, Ingarden subsumes the functional-energetic analysis of the literary work into his own structural-anatomical analysis. Through this dialogue with Łempicki, Ingarden has become comfortable speaking about the literary work as an object that-like a biological organism - reveals itself through both (1) physical structures of a more or less stable nature and (2) unfolding processes that are driven by a sort of internal energy.

8 For Łempicki $(1932,3)$, many "trivial” works of sensational and popular literature are such hollow, lifeless structures: they superficially appear to possess a sound literary structure but lack the dynamic internal energy of a true work of art.

9 Ingarden (1939) would later echo the language of the distinction made by Łempicki in, e.g., his discussion of the relationship between "anatomical-physiological changes" observed in another person and that individual's psychic state. 


\section{THE LITERARY WORK AS ORGANIC-STRUCTURAL AND TEMPORAL-DYNAMIC OBJECT: “FORMY POZNAWANIA DZIEŁA LITERACKIEGO” (1936)}

Three years later, Ingarden published a lengthier article on "Formy poznawania dzieła literackiego" in Pamiętnik Literacki. Here, Ingarden suggests that the literary work encompasses two interrelated dimensions. The first is a "multilayered structure" whose individual layers' particular construction gives rise to an "organic union" (zwiazek organiczny) between those layers and the "structural unity of the work" as a whole (Ingarden, 1936, 165, 181). Indeed, Ingarden explains that all masterworksincluding (but not limited to) literary masterworks-are characterized by such a high degree of coherence and "organicity" (organiczność) in their construction that the removal or distortion of even the tiniest element can result in the deformation of the entire work and the evaporation of all that is unique and essential within it (Ingarden, 1936, 180). Despite its importance, though, this multilayered structure only provides a sort of "skeleton" for the work (Ingarden, 1936, 179).

The literary work's second dimension is its ordering of the different temporal phases and parts that give it dynamic properties (Ingarden, 1936, 165). Such a work is constructed as a system of successive phases or parts that follow one another and are synthetically linked with one another (Ingarden, 1936, 183-184). We are unable to experience all of the work's distinct temporal phases-its entire system of temporal aspects-simultaneously (Ingarden, 1936, 189); it is only by actively experiencing such dynamic properties through time that a reader can perceive the polyphonic harmony of the aesthetically valent qualities of the work as a whole (Ingarden, 1936, 179). Here Ingarden once again employs the concept of boundaries and "closure": as a purely intentional object and a "whole that is closed within itself," the literary work is transcendent with regard to any particular psychic experiences of its author or readers ${ }^{10}$. This may be compared with Ingarden's $(1935,79,83)$ then-evolving understanding of every individual ontically autonomous object as a "whole" that is closed, self-contained, and delimited or "fenced off" on all sides ${ }^{11}$.

10 Ingarden $(1936,166)$ writes of the literary work of art that “[...] jest ono różne od wszelkich przeżyć psychicznych czy to autora, czy też czytelników, i jest w stosunku do nich transcendentne, t. zn. tworzy w stosunku do tych przeżyć całość w sobie zamkniętą."

11 While in his 1936 article Ingarden thus highlights the ways in which a literary work possesses some properties or being within itself and cannot simply be identified with or reduced to individual mental experiences of its readers, he would soon state definitively (Ingarden, 1937a, 51-52) that a literary work is not ontically autonomous (regarding that point, see Section 8.3. below). The fact 
In "Formy poznawania dzieła literackiego", Ingarden thus moves beyond the tentative understanding of the literary work as a dual (1) structural-anatomical and (2) functional-energetic object that he developed jointly with Łempicki to begin formulating his own, more rigorously reasoned understanding of the literary work as a dual (1) organic-structural and (2) temporal-dynamic object. Key concepts that will prove relevant in his later thought include those of "organicity," an organic union of structural elements, a system of temporal parts, and the notion of a transcendent multi-sided object that is a whole closed within itself.

\section{THE LITERARY WORK AND ACTIVE BOUNDARIES: "SPRAWA FORMY I TREŚCI W DZIELE LITERACKIM" (1937)}

Ingarden explores such questions again in "Sprawa formy i treści w dziele literackim" (1937b, 164). In attempting to distinguish a literary work's form from its matter, one possible approach that Ingarden (1937b, 157-58) highlights is an Aristotelian model that identifies the spatial form (or shape) of a material object with the "spatial boundaries of the material thing"; everything located within those boundaries comprises the object's "matter." Rather than understanding an object's visible boundary as an incidental side-effect produced by the structure and activity of the object's internal contents, such a view attributes the active role and conceptual priority to the boundary itself. This perspective foreshadows Ingarden's mature systems theory, with the critical role that it gives to semipermeable membranes in actively regulating the interior spaces and dynamics of a relatively isolated system. Here, Ingarden ultimately suggests that the "form" and "content" of a literary work can be analyzed from three perspectives: (1) a purely "anatomical" viewpoint that is limited to the work itself; (2) a "phenomenological-descriptive" perspective relating to the work's concretization; and (3) a "functional-aesthetic" perspective.

\section{THE LITERARY WORK AS ORGANICALLY BUILT HIERARCHICAL FUNCTIONAL-STRUCTURAL WHOLE: “O POZNAWANIU DZIEŁA LITERACKIEGO” (1937-1968)}

The layers of a literary work form "mutually harmonized elements of an organically built whole" (dostrojone do siebie człony organicznie zbudowanej całości) that is more than just an assortment of disconnected layers that happen to lie in proximity

that Ingarden held both of these positions to be true reflects the sophistication of his thinking on this issue. 
to one another (Ingarden, 1937a, 49). Ingarden considers Das literarische Kunstwerk to have addressed the question of how particular elements of a literary work produce such "organicity"; in O poznawaniu dzieła literackiego (1937a, 49-50), he wishes to clarify the theoretically prior question of exactly what the concept of "organicity" entails (which, to his mind, has never been satisfactorily answered).

\subsection{Distinguishing characteristics of the "organism"}

More particularly, what is it that distinguishes an "organism" from any other cluster of elements (Ingarden, 1937a, 50)? Ingarden proposes three answers. First, the organism does not simply "exist"; it also fulfills some overarching chief function to which the functions of its particular "organs" are subordinated. A biological organism's chief function is to preserve its own life, thereby enabling the production and maintenance of offspring and the long-term survival of the species. All other, more particular activities performed by the organism's organs (e.g., involving respiration, circulation, locomotion, sensation, obtaining food from the environment, digestion, or the secretion of waste products) are subordinated to that overall goal of the individual's survival (Ingarden, 1937a, 50). The second distinguishing characteristic of an organism is the fact that its hierarchical system (hierarchicznie ułożony system) of chief and supporting functions-the hierarchy of dynamic processes occurring within it -is mirrored in a similarly hierarchical system of physical structures in the form of the organism's individual organs (Ingarden, 1937a, 50). The third distinguishing characteristic of an organism is the fact that it displays a typical life cycle of growth, development, and decline, leading to an end (i.e., death) that is not "accidental" but is a natural result of the organism's structure and functioning.

\subsection{Isolation and interdependence in the organism}

By itself, no one organ is capable of fulfilling the organism's chief function of individual survival and the maintenance of the species; that can only be performed by the organism as a whole (Ingarden, 1937a, 50). In order for the organism as a whole to survive, an appropriate equilibrium must be maintained between the activities of all its organs: if the functioning of any one organ becomes too weak (or too strong), it can endanger the health of the entire organism (Ingarden, 1937a, 51). Such equilibrium is promoted by the organs themselves, which serve to support, regulate, and (when necessary) repair one another (Ingarden, 1937a, 50-51).

Regarding the role of "isolation," in the original 1937 version of $O$ poznawaniu dzieła literackiego, Ingarden $(1937 \mathrm{a}, 51)$ noted simply that an organism does not 
contain any completely isolated elements that are wholly isolated from (and thus functionally independent of) the remaining elements. However, in the revised edition from 1957, he significantly expands that line of thought, introducing a more detailed consideration of the question of partial isolation in biological systems that - we would argue-(a) draws on his maturing systems theory, as contained in the unfinished notes for volume III of Der Streit that he had composed in 1950-54 and (b) is a harbinger of the more developed theoretical biology of isolation that would be presented in 1970's Über die Verantwortung.

In the expanded account found in the 1957 edition, Ingarden $(1957,48)$ explains that while an organism does not contain any completely isolated or functionally independent components, it is equally true that particular organisms or organ systems are partially isolated from one another: i.e., they are isolated "at least to some extent and in certain regards, during appropriate periods of time," as evidenced by (a) the fact that such organs maintain their own unique functionality and normally behave in a manner that is relatively undisturbed by the activity of other organs and (b) organisms' possession of diverse "isolating mechanisms" (urzadzenia izolacyjne) like the diaphragm that separates the thoracic and abdominal cavities or the membranous meninges that protect the brain and spinal cord. This description of partial isolation resembles that found in the unpublished notes for Der Streit, volume III (in which Ingarden $(1974,102)$ described the relatively isolated system as being isolated during a certain time, in a certain respect, or to a certain degree), while the example of diaphragms and meninges as partial isolators would later be developed in much greater detail in Über die Verantwortung.

The addition of a deeper analysis of isolation in biological systems during Ingarden's revising of $O$ poznawaniu dzieła literackiego suggests (a) that he remained keenly interested in and committed to the systems theory that he had developed in his notes for volume III of Der Streit, despite the fact that he would never have an opportunity to complete that work, and (b) that by 1957, he believed that in order to help readers fully and properly understand his earlier literary aesthetics, it was useful (if not necessary) for him to incorporate a more detailed and explicit account of his biologically grounded systems theory.

\subsection{Comparing a literary work to an organism}

In O poznawaniu dzieła literackiego, Ingarden explains that a literary work cannot be a true organism, because it lacks autonomous being (byt samoistny); it owes the fact of its existence and structure of its contents to acts of consciousness on the part of 
its author and readers. However, one can-if only by way of a certain analogy or approximation (pewna analogia, przybliżeniem) - speak of a literary work as an "organism" (Ingarden, 1937a, 51-52). Here Ingarden focuses on two similarities between the literary work of art and a biological organism that allow the use of such language. First, a literary work's layers display a hierarchical interdependence resembling that of an organism's organs. Ingarden argues (in possible divergence from his earlier thought) that as a finished schematic creation considered apart from its concretizations, the literary work itself is unchanging, as no processes occur within it; this contrasts radically with the behavior of a living organism (Ingarden, 1937a, 52). However, when we move from the transcendent schematic work itself to the individual concretizations that are built up in the minds of individual readers during the reading process, various elements of the work begin to take on the appearance of activity, functionality, and life: particular elements fill supporting functional roles toward one another, and when the individual functions of the work's elements are allowed to develop, the work is able to show us its "organic" face in its concretization (Ingarden, 1937a, 52-53).

The second similarity between a literary work and an organism is the fact that each-taken as a whole-fulfills a single chief function. Just as an organism's dual functional-structural hierarchy supports the overall function of the survival of the individual, a literary work potentially (in itself as a schematic creation) and actually (in a particular reader's concretization) fulfills the main function that is its "sense," its "raison dêtre ", its "destiny" (Ingarden, 1937a, 57-58). Nonetheless, while Ingarden is certain that every literary work has a chief function, he acknowledges ongoing debate regarding what that function is (Ingarden, 1937a, 53). For him, the literary work's chief function is neither to express the thought of its author nor to convey some factual assertion, imperative, or moral (Ingarden, 1937a, 54-56); rather, the chief and proper function of a literary work (as a whole) is to help its reader to constitute one of those many potential aesthetic objects that belong to it and which it makes possible. All of the work's elements and subordinate functions should be directed toward achieving that chief function; if the work does not fulfill it, it nonetheless remains a literary work of art-but a "bad" or "misguided" one that is devoid of artistic value (Ingarden, 1937a, 57).

For Ingarden, constituting such an aesthetic object involves mentally experiencing a certain essential relationship of harmonized qualities that creates a unique qualitative whole and reveals itself to a given reader through some concrete visualization. This essential relationship is the "idea" of a literary work understood in its proper sense; it provides the work with the "organic uniformity of structure" (organiczna jednolitość budowy) that is visible in its concretization (Ingarden, 1937a, 58). Each 
layer of the literary work contributes different kinds of qualities that are all brought together in such a relationship, and the nature of the relationship as a whole differs for each literary work of art (Ingarden, 1937a, 58). This relationship always gives rise to a hierarchy in which some qualities are more vivid than others; that subset of vivid primary qualities provides a "crystallizing center" (ośrodek krystalizacyjny) (Ingarden, 1937a, 58-59) around which all other qualities are organized, to complement and accentuate the qualities of the crystallizing center. However, the nature of that center varies between literary genres and individual works: in one work, it may be the personalities or motivations of the leading characters that form the work's center, while in another it may be a theme of love or redemption or (e.g., in the case of certain poems or children's books) the sound of words or structure of sentences (Ingarden, 1937a, 58). Indeed, not only does the crystallizing center help structure the literary work's idea; it is the work's idea (Ingarden, 1937a, 59). The best works appear to be those that have exactly one crystallizing center: while such a work may have many complementary qualities that enhance its "polyphony," they are all subordinated to that one center (Ingarden, 1937a, 59) ${ }^{12}$. It is possible for a work to have several crystallizing centers that cannot be harmonized with or subordinated to one another (which may even lend a work a certain "charm"); however, such a work fails to present a "unitary face" (jednolite oblicze) and lacks a single qualitatively united "idea" (Ingarden, 1937a, 59).

A work's ultimate organic structure is only revealed to us by visualizing the work's "idea" under the influence of the work itself; to aid us in that task, one needs a certain sensitivity regarding how to best tease out and employ the hierarchy's many supporting qualities so that they might reveal that chief idea (Ingarden, 1937a, 5960). Many readers lack such a sensitivity, and as a result they are unable to grasp the essence of a given work of art; instead of experiencing it as a living entity with an organic uniformity and individual organic "face," they encounter only "a certain cold and dead skeleton of a literary work" (tylko pewien zimny i martwy szkielet dzieła literackiego) (Ingarden, 1937a, 60).

In the revised edition of the book published in German in 1968, Ingarden removed language (Ingarden, 1997, 85) referring to the "anatomical" (in)dependence of a literary work's layers, while simultaneously expanding use (Ingarden, 1997, 85) of the concept of "isolation," reflecting a shift away from Łempicki's language and toward Ingarden's own mature systems theory. He also elaborated his understanding of the

12 This description of the center that crystallizes the whole is reminiscent of the language that Ingarden will later employ in Über die Verantwortung (1970, 92-93) to describe the intentional "I" as the "organizing center" of the human soul. 
phases of an organism's life cycle (Ingarden, 1997, 84); explicitly connected (Ingarden, 1997,82 ) his theoretical biological account of literary works from $O$ poznawaniu $d z$ ieła literackiego (Ingarden, 1937a) with his later analysis of the "organic whole" in volumes I and II of the Spór o istnienie świata (Ingarden 1947, 1948b); and added a discussion of the way in which an organism's nervous system allows it to sense and react to its environment (Umwelt), in a manner reminiscent of Uexküll's (1928) understanding of the Umwelt as the union of Merkwelt and Wirkwelt ${ }^{13}$.

\subsection{Summarizing Ingarden's mature view}

By the end of his career, Ingarden had thus come to understand both (literary) works of art and biological organisms as systematically transforming, "living," functional-structural wholes that comprise a system of hierarchically arranged and partially isolated (yet interdependent) elements whose harmonizing interaction allows an entity to fulfill its chief function ${ }^{14}$. Indeed, both kinds of entities can be understood as particular types of relatively isolated systems-which suggests that the mutual resemblance of literary works and organisms is more than just metaphorical; the two kinds of entities are, in a sense, (ontological) "cousins."

13 Ingarden had studied and taken meticulous notes on Uexküll's Theoretische Biologie (1928) in 1943. Although that fact is not widely known, the notes are preserved in the archive of Ingarden's personal papers (Ingarden, 1943).

14 Due to space constraints, this historical analysis has focused on the direct links between Ingarden's theoretical biology and his literary aesthetics; a broader account of the evolution of Ingarden's theoretical biology and systems theory would also need to take into account, e.g., relevant passages in Ingarden (1947, 122, 260-261, 266; 1948a; 1948b, 161, 166-167, 553-556, 566, 848; 1960, 256-257) and Gierulanka (1981, 5-6). A turning point in the development of Ingarden's thought came in 1943, when he encountered Bertalanffy's Theoretische Biologie (1932), as recounted in Ingarden $(1947,255$; 1948b, 161; 2013, 272); Bertalanffy's concepts of the "open system" and "dynamic equilibrium" would provide Ingarden with inspiration for more rigorously developing his own systems theory. Ingarden similarly acknowledged $(1997,85)$ his reading of Rothschuh's Theorie des Organismus (1959). In lectures given in the months before his death, Ingarden would, in passing, again discuss Bertalanffy and various biologically grounded approaches to understanding the essence of an organism (offering a critique of the "machine-like" theory of the organism) (Ingarden, 1970a) and again note the complex synthetic nature of the organism (and "organicity") (Ingarden, 1970b). 


\section{CONTEMPORARY APPLICATIONS: THE COMPUTER GAME AS AN ORGANISM-LIKE ENTITY}

\subsection{Ingarden and contemporary studies of artificial life}

Since Ingarden's initial exposure to theoretical biology in the 1940s, the field has evolved in various ways. For example, as part of contemporary astrobiology, it explores what radically different forms of life might exist on alien planets whose environments bear little resemblance to that of our earth, while as part of synthetic biology, it investigates the extent to which novel biological life-forms might be artificially engineered here on earth ${ }^{15}$. Another branch of theoretical biology has become intertwined with the fields of artificial intelligence, computer science, and robotics, as it investigates whether sufficiently complex simulations, computer programs, computer networks, robots, or other digital-physical entities that have been artificially designed or arisen through evolutionary processes might theoretically possess some form of (artificial) "life"-and if so, how it would resemble or differ from the life of biological organisms ${ }^{16}$.

In some ways, Ingarden's study of the organism-like nature of the literary work of art foreshadowed elements of today's research into artificial life. While the investigation of the "life" of literary works that Ingarden launched in the 1920s and 1930s differs greatly from today's field of artificial life and its creation and analysis of digital-physical "organisms," both lines of thought broadly share a common approach: they posit that it may be possible and appropriate to describe certain non-biological entities or objects as being "alive" in a sense that is more than simply metaphorical, even though the kind of life possessed by such entities differs in some essential qualitative way from the life of biological organisms. The best contemporary comput-

15 Regarding the relationship between theoretical biology, astrobiology, and synthetic biology, see, e.g., Deplazes-Zemp (2012).

16 Olson (1997) develops an early (critical) exploration of such questions that explicitly compares the ontological status of purported forms of digital "artificial life" with the ontological status of works of fiction like novels and films-although the understanding of works of art presented there differs substantially from Ingarden's phenomenological aesthetic perspective. It should be noted that while the development of increasingly sophisticated technologies relating to robotics, evolutionary computation, and artificial intelligence has given new impetus to scholarly debate regarding what types of entities should be considered to be "alive," the same question arises in other contemporary contexts that have no connection with computer science or technology. For example, microbiologists and philosophers continue to debate whether the largest and most complex viruses should be considered to be "alive"; see, e.g., Forterre (2016). If such longstanding debates within the natural sciences have so far escaped definitive resolution, it should perhaps not be surprising if the question of whether the most sophisticated contemporary computer games are "alive," "non-alive," or "quasi-alive" should prove to be more complex than it might first appear. 
er games are sophisticated works of art that players access through highly dynamic, interactive, semiautonomous, artificially intelligent digital-physical systems; investigating the extent to which such games might be considered to be "organisms" thus provides an opportunity for linking Ingarden's aesthetic and ontological thought with current studies of artificial life.

\subsection{Computer games' similarities with earlier art forms understood as "organisms"}

In some ways, computer games possess organism-like characteristics very similar to those of older and more conventional types of artwork like novels or films. For example, while the computer game is a relatively young art form, it has existed long enough that some games developed in the 1980s have already undergone the sort of organic "life cycle" that Ingarden (1931, 359-369) describes: certain games that had been largely neglected for decades are now being revived and appreciated anew for their "retro" aesthetics, contents, and gameplay style ${ }^{17}$. Moreover, the fact that some persons (especially, though not exclusively, the young) readily lose themselves in the gameworld of certain computer games while other persons who are "non-gamers" perceive in the same works only a "cold and dead skeleton" (Ingarden, 1937a, 60) is consistent with Ingarden's suggestion that for any work of art, many recipients will lack the "sensitivity" needed to perceive the work as a living entity possessing an organic unity and single organic "face" (Ingarden, 1937a, 59-60) ${ }^{18}$.

\subsection{Computer games' differences from earlier art forms understood as "organisms"}

In other respects, a computer game would appear to be much more "alive" than a novel or film. Novels, films, and computer games all "live" by virtue of the fact that they are schematic constructs with areas of indeterminacy that must be "concretized" in diverse ways in the minds of individual recipients ${ }^{19}$. However, the typical computer game displays a much greater degree of "biodiversity" in its concretizations, due to the fact that while everyone reading a novel encounters (more or less) the same written

17 See, e.g., (Swalwell, 2007; Makai, 2018).

18 Regarding generational differences in the appreciation and use of computer games, see, e.g., (Brown \& Marston, 2018).

19 Regarding the role of concretization (in the Ingardenian sense) in computer gameplay, see, e.g., (Marak, Markocki, \& Brzostek, 2019, 9). 
words on the page and everyone watching a film experiences (more or less) the same shapes and colors appearing on the screen, different persons playing "the same" computer game may be presented with radically different schematic constructs to concretize-as the choices made by particular players within the game can, for example, cause one player to be shown entire geographical areas or experience whole subplots that are not presented to another player.

A typical computer game also possesses a more complex and robust "anatomy" and "physiology" than a novel or a film, insofar as it unifies into a seamless organic whole not only its constituent visual, literary, and musical works of art (which a film, too, possesses) but also the player's carefully choreographed movements, which represent a form of artistic "dance." Moreover, when a computer game is being played, the human player is not the only agent or actor involved: the game itself seems to possess a degree of agency that more traditional art forms lack; thanks to its sophisticated artificial intelligence and (reactive and proactive) agency, the typical computer game can dynamically "open" and "close" itself to players in ways impossible for "lifeless" objects (Ingarden, 1931, 139, 357). Indeed, many games are enjoyable precisely for the manner in which they work dynamically to "out-think" players by challenging, parrying, or anticipating their actions; such games detect, interpret, and respond to players' actions in real time in ways that other works of art cannot.

Might the possession of such "life-like" agency mean that a game truly is an organism-and not simply "organism-like"? From an Ingardenian perspective, we would argue that that is not the case. It is indeed true that a game system's hardware and software manifest a kind of agency vastly surpassing that of a relatively "passive," "insensitive," "indifferent" (Ingarden, 1931, 139, 357) work of art like a novel or film. However, Ingarden would contend that the "computer game" as a work of art is not to be identified with electrical activity occurring in a game console's circuits or with the emission of photons by its screen; the real "computer game" - just like the real "novel" or "film" - is a purely intentional object constituted in the mental acts of the conscious human mind that is experiencing it. The ontic autonomy and complex behavior of the physical game system can mask the fact that the (purely intentional) game itself lacks such ontic autonomy; it depends for its existence on the mental activity of a human player.

\section{CONCLUSION}

It would thus appear that the account of the organism-like features and "life" of a work of art that Ingarden developed thoughtfully over the course of decades is not directly undermined by the emergence of richly interactive and seemingly (artificial- 
ly) intelligent computer games, understood as works of art. At the same time, though, we would argue that the rise of computer games possessing robust forms of agency illustrates in a new context the importance of the exchange of ideas with Łempicki in which Ingarden engaged in 1931-33.

In response to Łempicki's observations, Ingarden acknowledged that the vision of the literary work of art that he had formulated in Das literarische Kunstwerk had emphasized the "anatomical" sense in which such a work contains a structure that is stable, passive, and inert. While Ingarden had not highlighted in Das literarische Kunstwerk the "physiological" sense in which a literary work of art possesses an internal energy or dynamism that actively seeks to express itself, he contended that such a functional-energetic analysis was entirely consistent with (and complementary to) his structural-anatomical analysis-and, indeed, that such a functional-energetic analysis could be readily built upon the ontological framework that he had developed. In the context of contemporary computer games, we would suggest that while Ingardenian aesthetic analyses of conventional works like novels, paintings, and films have highlighted the ways in which such works are purely intentional objects that lack ontic autonomy and agency, the rise of interactive, artificially intelligent computer games provides us with an opportunity (if not the need) to recover and explore another, less appreciated, aspect of Ingarden's thought: his acknowledgement that works of art can-despite their ultimate lack of ontic autonomy-demonstrate some form of dynamism, energy, and activity which resembles that of a living organism. Fully reconciling the structural-anatomical and functional-energetic strands within Ingarden's aesthetic thought in this manner is a project that remains to be completed, and the example of contemporary computer games suggests that it is an area that will become an increasingly fruitful field for philosophical reflection, as new forms of art continue to emerge that are ever more sophisticated, intelligent, active, and "alive."

\section{REFERENCES}

Bertalanffy, L. (1932). Theoretische Biologie: Erster Band: Allgemeine Theorie, Physikochemie, Aufbau und Entwicklung des Organismus. Berlin: Verlag von Gebrüder Borntraeger.

Brown, J. A., \& Marston, H.R. (2018). Gen X and Digital Games: Looking Back to Look Forward. In J.Zhou, \& G.Salvendy (Eds.), Human Aspects of IT for the Aged Population: Applications in Health, Assistance, and Entertainment (485-500). Cham: Springer.

Deplazes-Zemp, A. (2012). The Conception of Life in Synthetic Biology. Science and Engineering Ethics, $18,757-774$.

Forterre, P. (2016). To Be or Not to Be Alive: How Recent Discoveries Challenge the Traditional Definitions of Viruses and Life. Studies in History and Philosophy of Science. Part C: Studies in History and Philosophy of Biological and Biomedical Sciences, 59, 100-108. 
Gierulanka, D. (1981). Przedmowa tłumacza (D. Gierulanka, Trans.). In R. Ingarden, Spór o istnienie świata, Tom III: O strukturze przyczynowej realnego świata (5-12). Warszawa: Państwowe Wydawnictwo Naukowe.

Ingarden, R. (1919). Dążenia fenomenologów. Przegląd Filozoficzny, 22 (3), 118-156; 22 (4), 315-351. Ingarden, R. (1922a). Intuition und Intellekt bei Henri Bergson: Darstellung und Versuch einer Kritik. Jahrbuch für Philosophie und phänomenologische Forschung, 5, 285-461.

Ingarden, R.(1922b). W sprawie istoty doświadczenia wewnętrznego. Przegląd Filozoficzny, 25 (4), 512-534.

Ingarden, R. (1925). Essentiale Fragen: Ein Beitrag zum Wessensproblem. Jahrbuch für Philosophie und phänomenologische Forschung, 7, 125-304.

Ingarden, R. (1928). Max Scheler. Wspomnienie pośmiertne. Przegląd Filozoficzny, 31 (4), 343-351.

Ingarden, R. (1931). Das literarische Kunstwerk. Halle: Max Niemeyer Verlag.

Ingarden, R. (1933). Formy obcowania z dziełem literackiem. Wiadomości Literackie, 10 (7/478), 3.

Ingarden, R.(1935). Vom formalen Aufbau des individuellen Gegenstandes. Studia Philosophica, 1, 29-106.

Ingarden, R. (1936). Formy poznawania dzieła literackiego. Pamiętnik Literacki, 33, 163-192.

Ingarden, R.(1937a). O poznawaniu dzieła literackiego. Lwów: Wydawnictwo Zakładu Narodowego Imienia Ossolińskich.

Ingarden, R. (1937b). Sprawa formy i treści w dziele literackim. Życie Literackie, 5, 153-167.

Ingarden, R. (1939). O poznawaniu cudzych stanów psychicznych. Lecture at the meeting of the Lwowskie Towarzystwo Naukowe, Jan Kazimierz University, Lwów, June 6. Personal archive of Roman Ingarden, KIII-26, jednostek 84. Archiwum Nauki PAN i PAU, Kraków, Poland. Retrieved from http://ingarden.archive.uj.edu.pl/archiwum/odczyt-romana-ingardena-na-posiedzeniulwowskiego-towarzystwa-naukowego-z-15-06-1939

Ingarden, R. (1943). Manuscript notes on the "Theoretische Biologie" (1928) of Jakob von Uexküll. Personal archive of Roman Ingarden, KIII-26, jednostek 89/3. Archiwum Nauki PAN i PAU, Kraków, Poland.

Ingarden, R. (1947). Spór o istnienie świata, Vol. I. Kraków: Polska Akademia Umiejętności.

Ingarden, R. (1948a). Quelques remarques sur la relation de causalité. In Atti del Congresso Internazionale di Filosofia promosso dall'Istituto di studi filosofici (Roma, 15-20 novembre, 1946), vol. II: L'Esistenzialismo (573-577). Milano: Castellani.

Ingarden, R. (1948b). Spór o istnienie świata, Vol.II. Kraków: Polska Akademia Umiejętności.

Ingarden, R. (1957). O poznawaniu dzieła literackiego. In Studia z estetyki, Vol. 1 (1-251). Warszawa: Państwowe Wydawnictwo Naukowe.

Ingarden, R. (1960). Spór o istnienie świata, Vol. I. Warszawa: Państwowe Wydawnictwo Naukowe.

Ingarden, R. (1970a). O pojęciu istoty. Lecture at a scientific meeting of the Polish Philosophical Society, April 4. Personal archive of Roman Ingarden, KIII-26, jednostek 77. Archiwum Nauki PAN i PAU, Kraków, Poland. Retrieved from http://ingarden.archive.uj.edu.pl/archiwum/odczyt-romana-ingardena-o-pojeciu-istoty-z-04-04-1970

Ingarden, R. (1970b). Poznanie a priori u Kanta i Husserla. Lecture at a scientific meeting of the Polish Philosophical Society, March 21. Personal archive of Roman Ingarden, KIII-26, jednostek 77. Archiwum Nauki PAN i PAU, Kraków, Poland. Retrieved from http://ingarden.archive.uj.edu. $\mathrm{pl} /$ archiwum/odczyt-romana-ingardena-poznanie-a-priori-u-kanta-i-husserla-z-21-03-1970r

Ingarden, R. (1970c). Über die Verantwortung: Ihre ontischen Fundamente. Stuttgart: Reclam.

Ingarden, R. (1974). Über die kausale Struktur der realen Welt: Der Streit um die Existenz der Welt III. Tübingen: Max Niemeyer Verlag. 
Ingarden, R. (1983). Man and Value (A. Szylewicz, Trans.). München: Philosophia Verlag; Washington, DC: Catholic University of America Press.

Ingarden, R. (1988). O dziele literackim: Badania z pogranicza ontologii, teorii języka i filozofii literatury (M. Turowicz, Trans.). Warszawa: Państwowe Wydawnictwo Naukowe.

Ingarden, R. (1997). Vom Erkennen des literarischen Kunstwerks. Gesammelte Werke: Band 13 (E. M. Swiderski, Ed.). Tübingen: Max Niemeyer Verlag.

Ingarden, R. (2013). Controversy over the Existence of the World. Vol. I. Frankfurt: Peter Lang Edition.

Łempicki, Z. (1932). Dzieło literackie: Moc i działanie. Wiadomości Literackie, 9 (10/427), 3.

Makai, P. K. (2018). Video Games as Objects and Vehicles of Nostalgia. Humanities, 7 (4), 123.

Maluga, L. (2006). Autonomiczne rysunki architektoniczne. Wrocław: Oficyna Wydawnicza Politechniki Wrocławskiej.

Marak, K., Markocki, M., \& Brzostek, D.(2019). Gameplay, Emotions and Narrative: Independent Games Experienced. Pittsburgh: ETC Press.

Olson, E. T. (1997). The Ontological Basis of Strong Artificial Life. Artificial Life, 3 (1), 29-39.

Półtawski, A. (1978). The Idea and the Place of Human Creativity in the Philosophy of Roman Ingarden. Dialectics and Humanism, 5 (2), 129-140.

Rothschuh, K.E. (1959). Theorie des Organismus: Bios, Psyche, Pathos. München: Urban \& Schwarzenberg.

Scheler, M.(1923). Wesen und Formen der Sympathie: Der „Phänomenologie der Sympathiegefühle“. Bonn: Verlag von Friedrich Cohen.

Scheler, M. (1928). Die Stellung des Menschen im Kosmos. Darmstadt: Otto Reichl.

Sienkiewicz, P., \& Wojtala, R. (1991). Systems Thinking in Poland. In M. Jackson, G. Mansell, R. Flood, R. Blackham, \& S. Probert (Eds.), Systems Thinking in Europe (197-199). New York: Plenum Press.

Swalwell, M. (2007). The Remembering and the Forgetting of Early Digital Games: From Novelty to Detritus and Back Again. Journal of Visual Culture, 6 (2), 255-273.

Uexküll, J. (1928). Theoretische Biologie. Berlin: Verlag von Julius Springer. 